\title{
Expediency of Study of the Scientists' Biographies in Physics Course
}

\author{
Igor Korsun \\ Ternopil Volodymyr Hnatyuk National Pedagogical University, Ukraine, \\ korsun_igor@i.ua
}

1

The aim of this article is a justification of the expediency of study of the scientists biographies in physics course. Study of the biographic materials is one of the ways of motivation of learning and development of morality, humanity, internationalism. The selection criteria of biographic material have been allocated and method of study of the scientists' biographies has been described. Biographical data, scientific achievements and character traits are the components of "scientist's image". Results proved that the use of the biographic materials raises the level of emotional component of learners' cognitive activity in physics teaching. Method of study of the scientists' biographies can be used in teaching of other school subjects.

emotional component of cognitive activity

The most important endeavour is the striving for morality in our actions. Our inner balance and even our very existence depend on it. Only morality in our actions can give beauty and dignity for life.

\section{INTRODUCTION}

Albert Einstein

The problem of correlation between the rational and moral values of human personality is relevant today. For many people the ideal is a "business person", "professional". But "business man" must be a Human above all, and then be a professional. Otherwise there can be no question about the construction of any civilized society. Prime Minister of the United Kingdom Winston Churchill (1874-1965) was asked to cut arts funding in favour of the war effort during the Second World War. Some researchers attribute to him phrase: "Then what are we fighting for?" ("Winston Churchill - When Winston Churchill was asked to cut arts...", 2013). Known the words of Churchill in 1938: "The arts are essential to any complete national life" (Langworth, 2009).

There is another problem in Ukraine: a sharp increase in crime. But criminals are not born. It is a result of wrong upbringing. Teenagers watching action movies, they read books on history very seldom. Boxing is much more attracted the attention of Ukrainian youth, than a science or culture. Cognitive and educational television programs are almost absent on TV in Ukraine. In this way, school is a savior of situation. According

Citation: Korsun, I. (2017). Expediency of Study of the Scientists' Biographies in Physics Course. International Journal of Instruction, 10(2), 229-244. https://doi.org/10.12973/iji.2017.10215a 
to Plato: "School teachers have such powers that prime ministers can only dream about" ("Quotes").

Scientists create any science during many years. Carter (1993), Solomon (2002), LaçinŞimşek and Çalişkan (2016) have proved educational value of the history of science. McKinney and Michalovic (2004) said that "by using a wide variety of biographies and histories teachers can stimulate student interest, provide role models for all students, and generally give a more complete picture of the nature of scientific work" (p. 46). Therefore, studying of science without studying of the biographies of its founders will not allow to learners to understand the evolution of science.

The history of physics has a great potential for formation of interest to physics. Rowcliffe (2004) has proved that scientist's life stories are valuable resources for motivation of learning. Work of Eshach (2009) introduces a novel strategy for physics teaching: use of the Nobel Physics Prize as an organizational theme for high school or even first year university physics, bringing together history, social contexts of science, and central themes in modern physics. The idea is that the glamour and glitter of the Nobel Prize story may attract and motivate high school students to scientific topics and thus be spurred to pursue science. Hong and Lin-Siegler (2012) have proposed to use the images of scientists for formation of students' motivation to physics. Researchers have proved that the scientists' biographies are a mean for formation of motivation to learning. But problem of development of learners' morality with using of biographical material in physics teaching is not studied.

Education is not only a gaining of knowledge and formation of ability and skills. Education also plays an important role in the learners' development (e.g., development of thinking, morality and humanity). Veugelers (2011) said that "worldwide there is currently an enormous interest in values and norms and in the role of education in this matter" (p. 9). Vallejos (2014) and Yap (2014) have considered problem of formation of moral values in education. Ogrodzka-Mazur (2011), Maleš at al. (2014), Körük at al. (2016) have defined important role of link between family and school in the formation of moral values. But researchers studied not enough the ways of development of young people's morality and humanity in the teaching of school subjects. The aim of article is a justification of the expediency of study of the scientists' biographies in physics course.

\section{METHOD}

\section{Problems of study of the scientists' biographies}

Own teaching experience helped to formulate two problems of study of the scientists' biographies in physics course:

(1) limitations in time (little time at the lessons);

(2) selection of educational material (a lot of information, information is complex for learners).

Solutions of these two problems are the objectives of our research. Extracurricular activities (e.g., conducting of learners' conferences, seminars) can solve the first problem. There are detailed biographies of scientists (Cropper, 2001; Rogers, 2010). 
But often this information is intended for specialists and historians of science. This material is complex for learners. In this way, the question about the criteria for selection of educational material arises.

Golovko (2000) has identified criteria for the selection of historical material:

(1) organic connectedness with the curriculum;

(2) availability for understand;

(3) promote to the efficiency of learning;

(4) promote to the formation of interest to a physics as a to a subject and as to a science;

(5) promote to the humanization of education;

(6) promote to the education of national consciousness.

Given the above, we offer the following method of study of the scientists' biographies.

\section{Components of "scientist's image"}

We cannot talk about every scientist in physics course. Edification of opinions and life facts are the main criterion. The volume of material is different. In this way, study of biographic materials can be of two types: first, the detailed biographies of individual scientists and, secondly, the fragmentary biographical information. Biography of the scientist is not only a chronological set of events and dates in the life of a scientist. It is a "biography" of thoughts, words and actions on the background of the socio-political context, in which scientist lived and worked. Teachers must choose from biography the information that is most relevant for today's youth. Facts of life must confirm personal qualities of scientist. This material will form the spiritual world of the learner.

Constructor Mykola Kybal'chych (1853-1881) has been sentenced to death. The scientist developed the first world's project of space vehicle for few days before death. He scribbled scheme by a button on the wall of chamber in prison. Scottish scientist James Maxwell (1831-1879) knew that he would live no more than a month. But scientist hurried to Cambridge, where he had to finish his manuscript "Electricity". Scientists risked their lives for discoveries (e.g., Georg Richmann (1711-1753) was fatally struck with lightning during the study of atmospheric electricity). Many scientists were the very courageous people (e.g., French scientist Jacques Charles (1746-1823) flew on balloon for research; Ukrainian constructor Igor Sikorsky (1889-1972) tested the own helicopters). Stalin's regime unjustly has sentenced many Ukrainian scientists (e.g., Sergii Korol'ov (1906-1966), a constructor of the world's first artificial satellites and first spacecraft) and has killed (e.g., Georgii Langemak (1898-1938), an author of the term "Cosmonautics", main constructor of rocket launchers "Katyusha").

Words of scientist speak for themselves. Ukrainian scientist Ivan Puliui (1845-1918) is an inventor of "lamp of Puluj". It is a prototype of modern X-ray machines. He made the first in the world radiograph by using of this device. Thus, Ivan Puluj was the first who worked with X-Rays and used them for medical diagnostics (Mayba at al., 1997). Ivan Puliui said that there is no greater honour for an intelligent person than to protect his own and national honour and to work for his people's good to secure them a better fate without any reward ("Ivan Puliui", 2010). 
No need to portray scientists completely devoid of drawbacks. The history of science knows a lot of disputes between scientists. These examples will develop the critical thinking of learners. A dispute between Isaac Newton (1643-1727) and Robert Hooke (1635-1703) about discovery of the gravitational interaction law is famous. Maybe that Hooke suggested to Newton the basic ideas. Then legend about apple in Newton's garden is a beautiful legend only. "Lamp of Puluj" has been awarded with Silver Medal in International Electrotechnical Exhibition (Paris, 1881). German physicist Wilhelm Röntgen (1845-1923) discovered X-rays by using of "lamp of Puluj" and published his experiments 14 years later (1895). He has been awarded with Nobel Prize in Physics for discovery of X-rays in 1901. Known that Röntgen visited the laboratory of Prof. Puluj before discovery, and Ivan Puliui presented his lamp.

The abundance of compliments should not attract the attention to the scientist. Therefore, we should avoid expressions such as "the greatest scientist of Century", "the most significant achievement in the world of science". Appropriate to talk about the state of physics (or other science) before the works of scientist and his contribution to science. The great discovery is not a result of one scientist's work. Physics has been created also by many other scientists (mathematicians, chemists, biologists). For example, the law of conservation and transformation of energy has been used in the works of the ancient Greek scientist Archimedes (c. 287 BC - c. 212 BC). The scientist formulated the famous "golden rule" of mechanics. Leonardo da Vinci (1452-1519) said about the impossibility of perpetual motion machine. Italian scientist Galileo Galilei (1564-1642) applied the law of conservation and transformation of energy for solving mechanical problems. Gottfried Wilhelm Leibniz (1646-1716) was near to the formulation of the law. Different wordings of the law are presented in the works of Rene Descartes (1596-1650), Christiaan Huygens (1629-1695), Daniel Bernoulli (17001782), Leonhard Euler (1707-1783), Jean d'Alembert (1717-1783), Joseph-Louis Lagrange (1736-1813) and other scientists. In the middle of the XIX century, the final wording of the law of conservation and transformation of energy ("Energy can neither be created nor destroyed; rather, it transforms from one form to another") has been presented in the works of Robert Mayer (1814-1878), James Joule (1818-1889) and Hermann Helmholtz (1821-1894).

Study of scientists' biographies will help to better understand the complex process of becoming a science (Korsun, 2003a, p. 10). For complete understanding of scientist's role the teacher should mentally move learners to the historical era, in which scientist worked. Without this would be difficult to understand the conditions, in which the scientist worked. Demonstration of many physics phenomena and experiments on the modern equipment can create illusion of simplicity of execution of an experiment. German physicist and mathematician Georg Simon Ohm (1789-1854) was in extremely difficult conditions, beginning his studies in 1825 . Only a quarter of a century ago a constant current source has been invented, and no one could explain accurately: "what is electricity". Then were not concepts "amperage" and "resistance" (they have been explained by Ohm). It becomes clear how difficult it was to establish the Ohm's law. French physicist Claude Pouillet (1791-1868) established this law regardless of G. Ohm. 
Thereby, the scientific achievements of scientist contain the following elements:

(1) reasons which prompted the scientist to study the problem (e.g., social needs);

(2) method for solving of problem;

(3) difficulties of scientific research.

Scientist confirmed himself not only as a professional but also as a Human during the creative activity. He guided by certain moral norms. No doubt that science plays a major role in the life of a scientist. But researcher is living in society. He is interested with social and political problems. Scientist analyzes their and creates own moral position. Thereby, the scientist always feels responsible for the results of work. It creates the aspect of problem "science and morality" (e.g., inventions of dynamite, of atomic and hydrogen bombs). Alfred Nobel (1833-1896) is an inventor of dynamite. He spoke against the using of dynamite for military purposes. The scientist bequeathed his money for creation of Nobel Foundation. There are five Nobel Prizes: in Physics, in Chemistry, in medical science or Physiology, for literary work "in an ideal direction" and the fifth prize is to be given to the person or society that renders the greatest service to the cause of international fraternity, in the suppression or reduction of standing armies, or in the establishment or furtherance of peace congresses ("The Official Web Site of the Nobel Prize").

Thus, we defined components of "scientist's image" (Figure 1).

Figure 1

Components of "scientist's image"

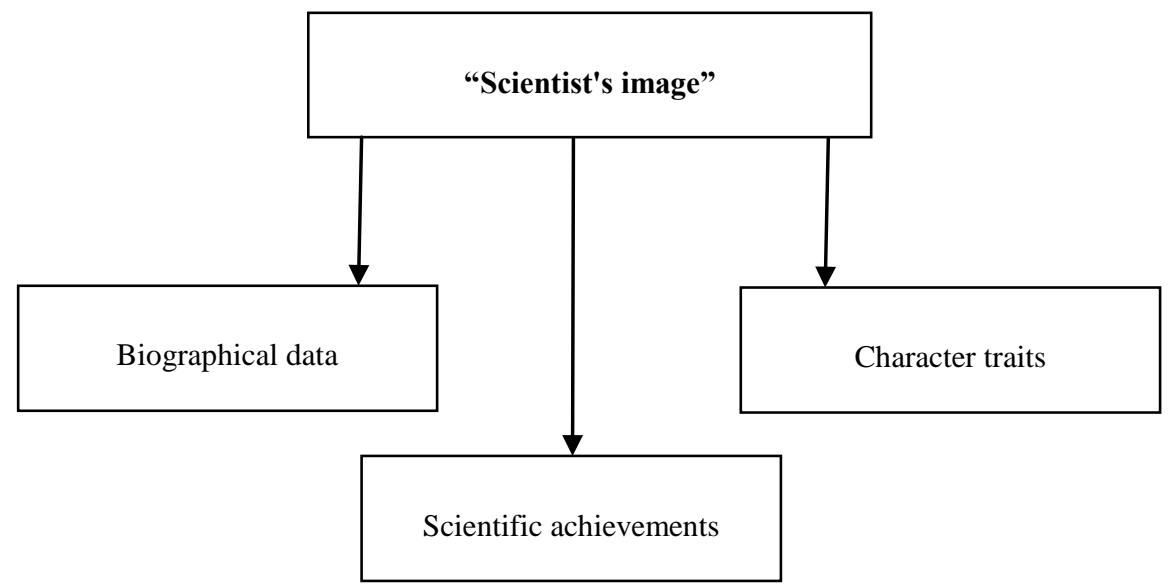

Example of "scientist's image"

International Journal of Instruction, April $2017 \bullet$ Vol.10, No.2 
Maria Skłodowska-Curie (1867, Warsaw, Poland - 1934, Haute Savoie, France) is a Polish physicist, chemist, educator and social activist.

Biographical data. Maria was the youngest of five children in the family of Vladislav and Bronislava Skłodowski. Her father taught physics in gymnasium, and mother was a gymnasium director. Science was held in high esteem in the family. Maria brilliantly graduated the primary school and secondary school. At young age she worked as a laboratory assistant in the chemical laboratory of her cousin. Marie Curie could not get education in Poland because of poverty of family (the girl's mother early died) and ban on education of women in University in Warsaw. With her sister Bronisława, they decided that Maria will work as a governess during five years. Her sister finished education in the medical institute. Then the older sister should take the cost of higher education of younger sister. Bronisława received her medical education in Paris, and then she invited her sister. At the age of 24 Marie Curie entered to the Faculty of Science in University of Paris (Sorbonne). In 1893, Maria received her licentiate on physics in Sorbonne (equivalent to Master's level). A year later she became licentiate on mathematics.

In 1894, Marie Sklodowska met French physicist Pierre Curie (1859-1906). Marie and Pierre married (1895), and their first daughter Irene was born in 1897. The scientific papers of Maria Skłodowska-Curie devoted to the study of the phenomenon of radioactivity. In July and December 1898, Maria Skłodowska-Curie and her husband Pierre Curie announced about the discovery of two new elements. One of these elements was a Polonium (Poland is the birthplace of Mary Skłodowska-Curie) and other element was a Radium. The family lived in a difficult financial situation. In 1900, M. Curie began to teach physics in pedagogical institution (Sèvres). Pierre Curie tragically died in a street accident (1906). Maria Sklodowska-Curie died from radiation sickness in 1934.

In 1958, visitors of the World Expo in Brussels ("Expo 58") saw an unusual exposure. Geiger counter constantly clicked near a small diary. It was one of Maria SklodowskaCuries' diaries... The eldest daughter of Curies became a famous scientist. In 1935, Irène Joliot-Curie (1897-1956) and her husband Frédéric Joliot-Curie (1900-1958) have been awarded with Nobel Prize in Chemistry for "In recognition of their synthesis of new radioactive elements". The younger daughter Ėve Curie Labouisse (1904-2007) became a known concert pianist, journalist, writer, public figure and biographer of her mother.

Scientific achievements. Maria Skłodowska-Curie is the first ever double winner of the Nobel Prize in Physics ("For outstanding achievements in joint studies of radiation effects", together with Pierre Curie, 1903) and in Chemistry ("In recognition of her services to the advancement of chemistry by the discovery of the elements radium and polonium, by the isolation of radium and the study of the nature and compounds of this remarkable element", 1911). She has been awarded with Davy Medal for "research of Radium" (together with Pierre Curie, 1903), Matteucci Medal (1904) for fundamental contributions to the progress of science and Willard Gibbs Award (1921). The purpose of Willard Gibbs Award is "to publicly recognize eminent chemists who, through years of application and devotion, have brought to the world developments that enable everyone to live more comfortably and to understand this world better". Maria 
Skłodowska-Curie was the first European woman, who was awarded a doctorate in science. Only two women (Maria Skłodowska-Curie and Maria Goeppert Mayer) are the winners of Nobel Prize in Physics ("The Official Web Site of the Nobel Prize"). In 2009, readers of journal "New Scientist" admitted that Maria Sklodowska-Curie is the most prominent female scientist of all time ("Most inspirational woman scientist revealed", 2009).

Character traits. For many years the married couple Curies worked in unhealthy conditions. The scientists had the burns (as Antoine Henri Becquerel (1852-1908), who discovered radioactivity). They suggested that radium could be used for treat of tumors. Therapeutic value of radium has been recognized, and prices on radium rose sharply. However the Curie refused to patent his invention and to use their findings for any commercial purposes. In their view, the commercial gain is not in the spirit of science and idea of free access to knowledge. Maria Sklodowska-Curie gave $80 \mathrm{mg}$ radium to Lviv (Ukraine). In 1920, her laboratory had only a little more than 1 gram of radium. Therefore, the first small radiology department emerged in Lviv, which contributed to the treatment of cancer patients (Peleschyshyn, 2011).

Some statements of Maria Sklodowska-Curie:

I am among those who think that science has great beauty.

After all, science is essentially international, and it is only through lack of the historical sense that national qualities have been attributed to it.

Be less curious about people and more curious about ideas.

All my life through, the new sights of Nature made me rejoice like a child.

We cannot hope to build a better world without improving the individual. Toward this end, each of us must work for his own highest development, accepting at the same time his share of responsibility in the general life of humanity - our particular duty being to aid those to whom we think we can be most useful ("Science Quotes by Marie Curie").

\section{Research Design}

In this study, quasi-experimental design is used. Hypothesis of research: the use of the biographic materials raises the level of emotional component of learners' cognitive activity in physics teaching. Marianenko (1992) developed the methodology of measuring the levels of cognitive activity. This methodology is aimed on diagnosis of structural components of cognitive activity: motivational, content (ability and skills) and emotional. The motivational component of cognitive activity is a positive attitude of learners to learning, a cognitive interest to school subject, and the desire to knowledge. The formation of thinking and cognitive processes (of perception, attention, imagination and memory) is a content of cognitive activity. The positive emotions, diligence, ability to organize own learning, self-control and self-improvement are the elements of the emotional component of cognitive activity.

\section{Sample}


Pedagogical experiment has been conducted in 7, 8 and 9 classes (age of learners is 1315 years) during 2015-2016 academic year. Five classes of the control group (122 learners) and five classes of the experimental group (120 learners) took part in pedagogical experiment. Teachers used the questionnaire method. Each learner filled the questionnaire (Table 1).

Table 1

List of questions

\begin{tabular}{l}
\hline Question \\
\hline 1. You know a name of the scientist who established a physics law (please \\
write name of scientist and title of law) \\
\hline 2. You know an inventor of some physics device (please write name of \\
inventor and title of device) \\
\hline 3. You know an interesting information about life of any physicist (please write \\
name of physicist and explanation) \\
\hline 4. You have a favorite scientist (please write name of scientist and explanation) \\
\hline 5. You know an example of a moral deed of any scientist (please write \\
example) \\
\hline 6. You know a saying of any physicist (please write the saying of physicist) \\
\hline 7. You know a name of scientist, who is a winner of the Nobel Prize in Physics \\
(please write name of scientist) \\
\hline 8. You read an additional literature on physics (please write title of book) \\
\hline
\end{tabular}

Evaluation:

0-3 "yes" - low level of emotional component

4-6 "yes" - average level of emotional component

7-8 "yes" - high level of emotional component

\section{Procedure}

At the beginning of academic year the assessment of emotion component of cognitive activity in both groups has been carried out (pre-test). During academic year the teaching of physics in the experimental group (EG) has been conducted with using of biographic material, and in the control group (CG) the teaching of physics has been conducted without using of biographic material. At the end of academic year the assessment of emotion component of cognitive activity in both groups has been carried out (post-test).

\section{FINDINGS}

\section{Data Analysis}

There were three levels of emotional component of cognitive activity (low, average, high). According to questioning, the level of emotional component of cognitive activity for each learner has been determined. The number of learners for each level of emotion component of cognitive activity has been determined (Table 2).

Table 2 
Results of measurements in CG and EG

\begin{tabular}{lcccc}
\hline The level of emotional component & \multicolumn{2}{c}{ Pre-test (\%) } & \multicolumn{2}{c}{ Post-test (\%) } \\
\hline & CG & EG & CG & EG \\
\hline low & 25.5 & 28.0 & 26.0 & 15.0 \\
\hline average & 48.0 & 48.0 & 50.0 & 54.0 \\
\hline high & 26.5 & 24.0 & 24.0 & 31.0 \\
\hline
\end{tabular}

Results of pedagogical experiment can be represented graphically (Figure 2, Figure 3).

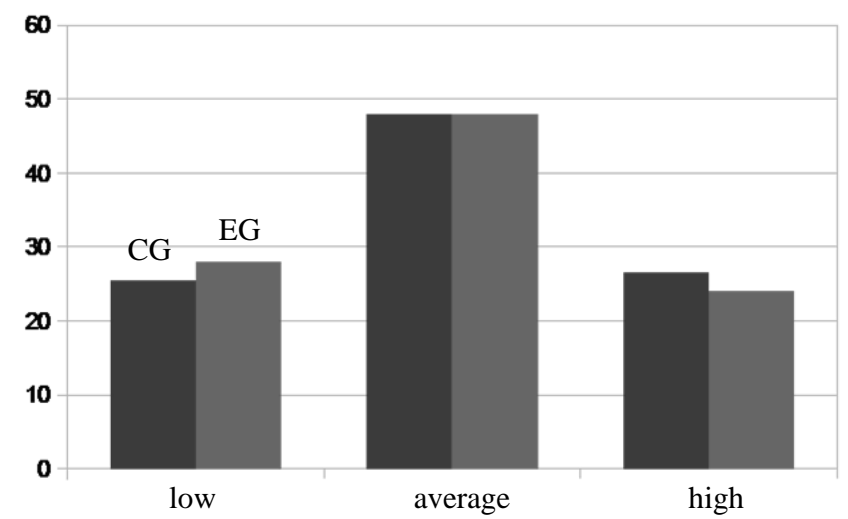

Figure 2

Results of pre-test

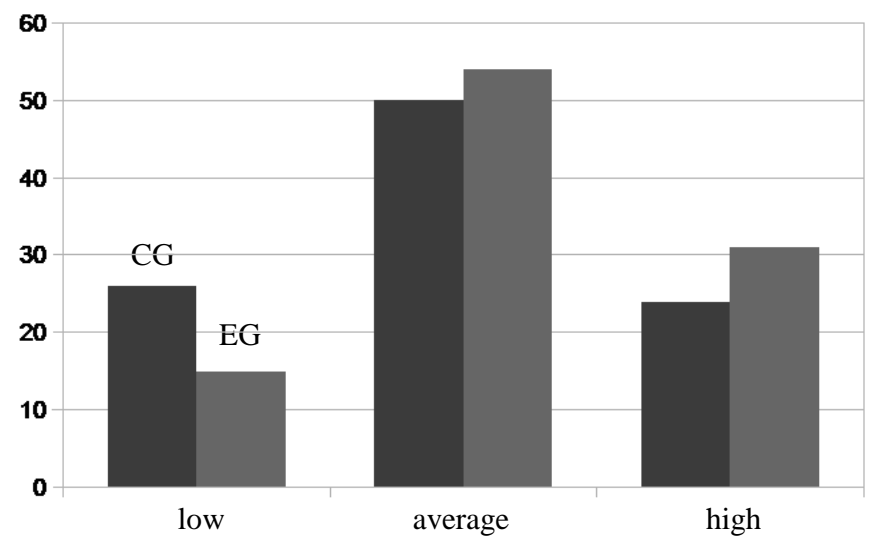

Figure 3

Results of post-test

\section{Statistical analyses}


Two statistical hypotheses were formulated for analyzing the results of the experiment:

(1) the null hypothesis (there is no difference between the distributions);

(2) the alternative hypothesis (there is a difference between the distributions).

We used Pearson's criterion $\chi^{2}$ for the decision about which of the hypotheses (null or alternative) should be recognized. We conducted measurements in a three-level scale of gradation (high, average and low levels). Significance level is 0.05 . The critical theoretical value $\chi_{0.05}^{2}$ for the significance level 0.05 in the three-level scale of gradation was: $\chi_{0.05}^{2}=5.99$. The empirical value $\chi_{\chi_{\text {empirical }}^{2}}$ of measured levels in CG and EG for the post-test was: $\chi_{\text {empirical }}^{2}=7.32$. Because that $\chi_{\text {empirical }}^{2}>\chi_{0.05}^{2}$, then the accuracy of statistical significance of characteristics of EG and CG for the post-test is $95 \%$.

Thus, analysis of pedagogical experiment confirmed the alternative hypothesis: the difference between theoretical and empirical values of Pearson's criterion has occurred with not accidental, but with essential reasons (implementation of the method of study of the scientists' biographies).

\section{DISCUSSION}

The development of science and technology affects the economy of any country in the world. Any economically developed country pays great attention to the development of science. Profession of scientist is prestigious in this country. The position of science is a very poor in terms of funding in Ukraine. In this way, we can not talk about the prestige of the profession of scientist in Ukraine. Small number of graduates wants to become by mathematicians, physicists, chemists. Therefore, we did not consider link between study of the scientists' biographies and professional choice of learners.

Learners study the different physics laws. But learners not receive the enough information about the creators of physics laws (results of pre-test). An educational activity of learner is similar with the scientific activities of scholar. The scientist makes the discoveries. A learner also is a "discoverer" of own world in the learning process. Many years ago a famous teacher V. Sukhomlynskyi (1971) said that the world enters to the century of Human; we have to think about what we put to the soul of human ( $p$. 198). These words are very relevant today. Each lesson should be a discovery not only of knowledge, but also a discovery of emotions. It is difficult to teach physics without aesthetic attitude to science (Korsun, 2003b, p. 76). Perception of educational material depends from the emotional mood of learners. Emotions affect on thinking and memory of learners. A low level of emotional component of cognitive activity negatively affects on the level and quality of learners' knowledge (results of experiment).

We have showed that familiarization with activities of Ukrainian scientists enables to implement the national component in physics teaching (Korsun \& Syrotjuk, 2005; Korsun, 2017). This provides the patriotic education of youth. Highlighting of the contribution of scientists of certain nationality to science in any case should not cause to national strife. In this way, teachers have to be careful in the choice of educational materials and forms of its presentation. The main principle: physics as any other science 
is an international science. Science should unite, not divide peoples. It should be a foundation of peace in world.

\section{CONCLUSION}

The problem of young people's morality and humanity is relevant in today's world. Not all learners will be the nice professionals in the future, but all of them must to be the Humans. Role of teachers in solving this problem is an important. The history of science and technology is essential for development of youth. This information helps to learners better understand the significance of modern science and technology. Study of the biographic materials is one of the ways of development of morality, humanity and internationalism. The life of many scientists is an example of devotion to science. This will raise respect to science research activities. Information about scientists encouraged the learners to read additional literature and to the own researches. Learners prepared reports about scientists. In these cases, biographies of scientists were a mean of formation of interest to a school subject.

The selection criteria of biographic material have been allocated and method of study of the scientists' biographies has been described. The components of "scientist's image" have been defined. These are biographical data, scientific achievements and character traits. The positive emotions, diligence, ability to organize own learning, self-control and self-improvement are the elements of the emotional component of cognitive activity. Results proved that the use of the biographic materials raises the level of emotional component of learners' cognitive activity in physics teaching.

Teachers can not limited with textbook's material and must to use the other sources of information (e.g., books, websites). Biographical material has been reported at the lessons and during the extracurricular activities (e.g., conducting of learners' conferences). Biography of the scientist must be analysed. "Educational" biography must demonstrate a scholar, citizen and Human. Every science has its history. In this way, method of study of the scientists' biographies can be used in teaching of other school subjects.

\section{REFERENCES}

Carter, K. (1993). The place of story in the study of teaching and teacher education. Educational Researcher, 22(1), 5-12.

Cropper, W.H. (2001). Great Physicists: The life and times of leading physicists from galileo to hawking. New York: Oxford University Press.

Eshach, H. (2009). The Nobel Prize in the physics class: Science, history, and glamour. Science \& Education, 18, 1377-1393. doi: 10.1007/s11191-008-9172-4.

Golovko, M. (2000). Onovlennia zmistu shkil'noi fizychnoi osvity z vykorystanniam materialiv $\mathrm{z}$ istorii vitchyznianoi nauky [Update of the content of school physics course with the use of the materials on the history of national science]. Fizyka ta astronomiia $v$ shkoli [Physics and Astronomy in School], 1, 12-16 (in Ukrainian). 
Hong, H.Y. \& Lin-Siegler, X. (2012). How learning about scientists' struggles influences students' interest and learning in Physics. Journal of Educational Psychology, 104(2), 469-484. doi: 10.1037/a0026224.

Ivan Puliui (2010, January 25). Retrieved from http://www.bank.gov.ua/control/en/currentmoney/cmcoin/details;jsessionid=1FD4BBD3 110D16364451A25B658D409B?coin_id=459 (10 October 2016).

Korsun, I. (2003a). Vykorystannia istorychnykh vidomostei yak zasib vykhovannia pry navchanni fizyky [Use of historical data as a mean of upbringing in physics teaching]. In: Materials of the Second International Scientific Conference "The Dynamics of Scientific Research'2003”. Dnipropetrovs'k, 10-11 (in Ukrainian).

Korsun, I. (2003b) Istoryzm yak dzherelo formuvannia piznaval'nykh interesiv uchniv na urokakh fizyky [Historicism as a source of formation of learners' cognitive interests in physics lessons]. In: Scientific reports of Ukrainian Scientific Conference "The Theory and Practice of Modern Natural Sciences", Kherson, 75-76 (in Ukrainian).

Korsun, I. \& Syrotjuk, V. (2005). Istoryzm yak zasib formuvannia natsional'nogo samousvidomlennia uchniv u protsesi vyvchennia shkil'nogo kursu fizyky [Historicism as a mean of formation of learners' national self-awareness during the study of school physics course]. Collection of scientific papers Kamianets-Podilsky Ivan Ohienko National University, 11, 41-42. Retrieved from http://journals.uran.ua/index.php/23074507/article/view/35388/31509 (2 October 2016) (in Ukrainian).

Korsun, I. (2017). Contribution of Ukrainian scientists to the development of quantum physics. Ukrainian Journal of Physics, 62(1), 67-79. doi: 10.15407/ujpe62.01.0067.

Körük, S., Öztürk, A., \& Kara, A. (2016). The predictive strength of perceived parenting and parental attachment styles on psychological symptoms among Turkish university students. International Journal of Instruction, 9(2), 215-230. Retrieved from http://www.e-iji.net/dosyalar/iji_2016_2_15.pdf (2 October 2016).

Laçin-Şimşek, C. \& Çalişkan, H. (2016). Scale development on educational value of the history of Science. Journal of Turkish Science Education, 13(3), 173-184. doi: 10.12973/tused.10178a.

Langworth, R.M. (2009, March 7). Safeguarding the Arts. Retrieved from https://richardlangworth.com/arts (2 October 2016).

Maleš, D., Kušević, B., \& Širanović, A. (2014). Child participation in family-school cooperation. C.E.P.S Journal, 4(1), 121-136.

Marianenko, L. (1992). Psykholohichni umovy formuvannia piznaval'noi aktyvnosti slabovstyhaiuchykh starshoklasnykiv [The psychological conditions of formation of the senior pupils' cognitive activity, who poorly study]. (Candidate dissertation). Institute of Psychology Ukraine, Kyiv (in Ukrainian).

Mayba, I., Gaida, R., Kyle, R., \& Shampo, M. (1997).Ukrainian Physicist contributes to the discovery of $X$-rays. Retrieved from 
http://web.archive.org/web/20080528172938/http://www.meduniv.lviv.ua/oldsite/puluj. html (10 October 2016).

McKinney, D. \& Michalovic, M. (2004). Teaching the stories of scientists and their discoveries. Science Teacher, 71(9), 46-51.

Memorable Albert Einstein Quotes. Retrieved from http://www.aslassociates.com/einsteinquotes.htm (1 October 2016).

Most inspirational woman scientist revealed (2009, July 1). Retrieved from https://www.newscientist.com/article/mg20327156-600-most-inspirational-womanscientist-revealed/ (10 October 2016).

Ogrodzka-Mazur, E. (2011). Family-child-school. Continuity and change of cultural transmission in the Borderland environment. The New Educational Review, 26(4), 158170.

Peleschyshyn, A. (2011, April 8). Mariia Sklodovs'ka-Kiuri u L'vivs'kii politekhnitsi [Maria Sklodowska-Curie in Lviv polytechnic]. Retrieved from http://www.naukaonline.org/content/mariya-sklodovska-kyuri-lvivskiy-politekhnitsi (2 October 2016) (in Ukrainian).

Quotes. Retrieved from http://statusmind.com/funny-facebook-status-60/ (15 October 2016).

Rogers, K. (2010). The 100 most influential scientists of all time. New York: Britannica Educational Publishing.

Rowcliffe, S. (2004). Storytelling in science. School Science Review, 86(314), 121-126.

Science Quotes by Marie Curie. Retrieved from http://todayinsci.com/C/Curie_Marie/CurieMarie-Quotations.htm (10 October 2016).

Solomon, J. (2002). Science stories and science texts: What can they do for our students? Studies in Science Education, 37, 85-105. doi: 10.1080/ 03057260208560178.

Sukhomlynskyi, V. (1971). Razgovor s molodym direktorom shkoly [The conversation with young director of school]. Moscow (in Russian).

The Official Web Site of the Nobel Prize. Retrieved from http://www.nobelprize.org/nobel_prizes/physics/ (10 October 2016).

Vallejos, R.M. (2014). Ética de la vida familiar y transmisión de valores morales [Ethics of family life and transmission of moral values]. Revista de Educación, 363, 210-229. doi: 10.4438/1988-592X-RE-2012-363-178 (in Spanish).

Veugelers, W. (2011). A humanist perspective on moral development and citizenship education. In W. Veugelers (Ed.), Education and humanism, 9-34. Rotterdam / Boston / Taipei: Sense Publishers.

Winston Churchill - When Winston Churchill was asked to cut arts... (2013, September 1). Retrieved from http://quotefail.com/people/winston-churchill (2 October 2016). 
Yap, S.F. (2014). Beliefs, values, ethics and moral reasoning in socioscientific education. Issues in Educational Research, 24(3), 299-319. Retrieved from http://www.iier.org.au/iier24/yap.html (10 October 2016).

\section{Turkish Abstract \\ Fizik Öğretiminde Bilimadamlarının Biyografilerinin Kullanılmasının Amaca Uygunluğu}

$\mathrm{Bu}$ makalenin amacı, fizik öğretimi boyunca bilimadamlarının biyografilerinin çalışılmasının amaca uygunluğunu araştırmaktır. Bilimadamlarının biyografilerinin kulanılmasını sınırlayan iki faktör vardır: Zaman sınırı ve eğitimsel materyal seçimi. Bu problemlerin çözümü çalışmanın amacını oluşturmaktadır. Eğitsel materyal seçimi ölçütü ve rehber materyal yöntemi tanımlanmıştır. Bilimadamının imaj bileșenleri (Biyografik veri, bilimsel başarılar, karakter analizi) tanımlanmıştır. $\mathrm{Bu}$ pedogojik deneyin sonuçları fizik öğretimi boyunca biyografik materyal kullanımı öğrencilerin bilişsel aktivitelerinin duyuşsal bileşenini arttırdığını kanıtlamıştır. Bilişsel aktivitenin duyuşsal bileşenleri, olumlu duygular, çaba, kendi kendine öğrenme becerisi, özkontrol ve özgelişimdir. Bilimadamlarının biyografilerinin kullanılması yöntemi diğer okul materyalleri ile birlikte uygulanmıştır.

Anahtar Kelimeler: öğrenciler, etik, insanlık, fizik öğretimi, bilimadamlarının biyografileri, bilişsel aktivitenin duyuşsal bileşenleri

\section{French Abstract}

\section{L'opportunité d'étude des biographies des scientifiques pendant l'enseignement de physique}

Le but d'article est une justification pour l'opportunité d'étude des biographies des scientifiques pendant l'enseignement de physique. La limitation à temps(dans le temps) et la sélection de matériel didactique est les deux problèmes d'étude des biographies des scientifiques. Les solutions de ces problèmes sont les objectifs de l'étude. Les critères de sélection de matériel didactique ont été alloués(répartis) et la méthode d'alimenter le matériel(la matière) a été décrite. Les composants "de l'image du scientifique" (des données biographiques, des accomplissements scientifiques, des traits de caractère) ont été définis. Les résultats d'expérience pédagogique en ont prouvé l'hypothèse de recherche l'utilisation des matériels(matières) biographiques augmente(lève) le niveau du composant émotionnel des élèves d'activité cognitive pendant l'enseignement de physique. Les émotions positives, la diligence, la capacité d'organiser le propre apprentissage, le sang-froid et des progrès personnels sont les éléments du composant émotionnel d'activité cognitive. La méthode d'étude des biographies des scientifiques peut être utilisée pendant l'enseignement d'autres matières scolaires.

Mots Clés: élèves, moralité, humanité, enseignement de physique, les biographies de scientifiques, composant émotionnel d'activité cognitive 


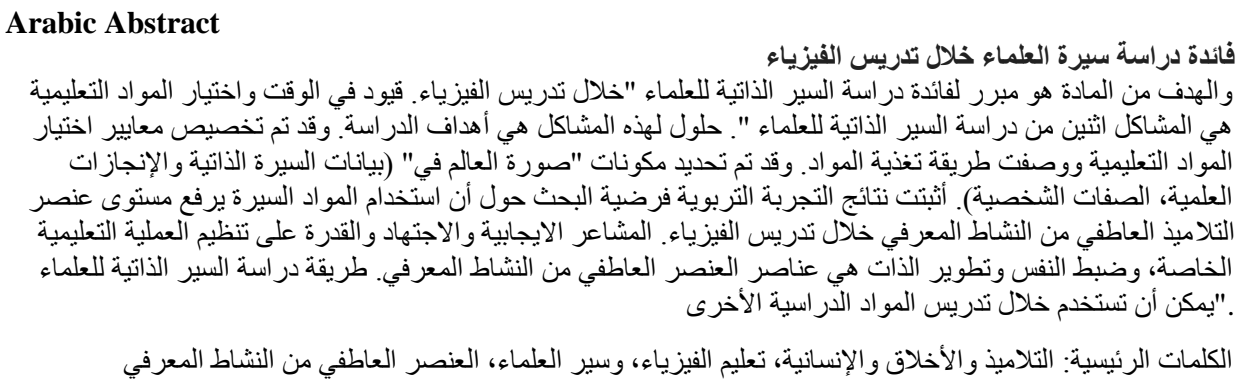

\section{German Abstract \\ Die Zweckmäßigkeit des Studiums der Biographien der Wissenschaftler während des Physikunterrichts}

Das Ziel des Artikels ist eine Rechtfertigung für die Zweckmäßigkeit des Studiums der Biographien der Wissenschaftler während des Physikunterrichts. Begrenzung der Zeit und Auswahl des Bildungsmaterials sind die beiden Probleme des Studiums der Biographien der Wissenschaftler. Lösungen dieser Probleme sind die Ziele der Studie. Die Auswahlkriterien des Bildungsmaterials wurden vergeben und die Methode der Fütterung des Materials wurde beschrieben. Die Bestandteile des "Wissenschaftlerbildes" (biographische Daten, wissenschaftliche Errungenschaften, Charaktermerkmale) wurden definiert. Die Ergebnisse des pädagogischen Experiments zeigten die Hypothese der Forschung darüber, dass die Verwendung der biografischen Materialien die emotionale Komponente der kognitiven Aktivität der Schüler während der Physik lehrt. Die positiven Emotionen, die Sorgfalt, die Fähigkeit, eigenes Lernen, Selbstbeherrschung und Selbstverbesserung zu organisieren, sind die Elemente der emotionalen Komponente der kognitiven Tätigkeit. Die Methode des Studiums der Biographien der Wissenschaftler kann während des Unterrichts anderer Schulfächer verwendet werden.

Schlüsselwörter: schüler, moral, menschlichkeit, physikunterricht, biographien von wissenschaftlern, emotionale komponente der kognitiven tätigkeit

\section{Malaysian Abstract \\ Kesesuaian Kajian Biografi Para saintis 'dalam Fizik Kursus}

Tujuan artikel adalah satu justifikasi bagi mengkaji kepentingan biografi para saintis 'semasa pengajaran fizik. Batas waktu dan pemilihan bahan pendidikan adalah dua masalah belajar biografi para saintis. Penyelesaian masalah ini adalah objektif kajian ini. Kriteria pemilihan bahan pendidikan telah diperuntukkan dan kaedah memberi makan bahan yang telah diterangkan. Komponen "imej saintis" (data biografi, pencapaian saintifik, sifat-sifat watak) telah ditentukan. Hasil daripada kajian pedagogi membuktikan hipotesis penyelidikan bahawa penggunaan bahanbahan biografi meningkatkan tahap komponen emosi murid aktiviti kognitif semasa pengajaran fizik. Emosi positif, usaha, keupayaan untuk mengatur pembelajaran sendiri, kawalan diri dan peningkatan diri adalah unsur-unsur komponen emosi aktiviti kognitif. Kaedah mengkaji biografi 
para saintis 'boleh digunakan semasa mata pelajaran sekolah lain ketika mengajar.

Kata Kunci: murid, moral, kemanusiaan, pengajaran fizik, biografi saintis, komponen emosi aktiviti kognitif

\section{Russian Abstract}

\section{Целесообразность Изучения Биографий Ученых При Преподавании Физики}

Цель статьи - обоснование целесообразности изучения биографий ученых при преподавании физики. Ограничение во времени и выбор учебного материала - это две проблемы изучения биографий ученых. Целями исследования и является изучение этих проблем. Были выделены критерии отбора учебного материала и описан способ подачи материала. Были определены данные, которые входили в "образ ученого" - это биографические данные, научные достижения, черты характера. Результаты педагогического эксперимента подтвердили гипотезу исследования о том, что использование биографических материалов повышает уровень эмоциональной составляющей когнитивной активности учащихся в процессе преподавания физики. Позитивные эмоции, трудолюбие, способность организовывать собственное обучение, самоконтроль и самосовершенствование являются элементами эмоционального компонента когнитивной деятельности. Метод изучения биографий ученых может быть использован при обучении другим школьным предметам.

Ключевые Слова: ученики, мораль, ч человечность, преподавание физики, биографии ученых, эмоциональный компонент когнитивной деятельности 